\title{
EFEKTIVITAS PENGGUNAAN METODE AUDIO VISUAL TERHADAP PENINGKATAN PENGETAHUAN REMAJA TENTANG SEKS SEBELUM MENIKAH
}

\author{
Vera Renta Siahaan ${ }^{1}$, Jehani Fajar Pangestuํㄹ ${ }^{2}$ Miftah Fitriyani ${ }^{3}$ \\ 1Dosen Poltekkes Kemenkes Medan \\ Email : vio_vera@yahoo.com \\ ${ }^{3}$ Dosen Poltekkes Kemenkes Pontianak \\ Email : jejahanini@gmail.com \\ ${ }^{3}$ Dosen Poltekkes Kemenkes Pontianak \\ Email : ginta.afrina@gmail.com
}

\begin{abstract}
Background: The survey found the reasons for premarital sexual relations were; curiosity (57,5\% reported by men), accidentally happened and being forced by partners were reported by women (38\% and 12,6\%). Result from interviews with the 10 students found 9 students have been dating and most of them didn't know about premarital sex. Health education was one of the efforts that could conducted to provide precise and accurate information relating to the dangers of premarital sex in adolescents. The methods that can be done to support the implementation of health education are lectures, pamphlets, leaflets and audio visuals. Audio visual can make a person concentrate more and attention and can encourage self-activity (Musfiqon, 2012). Based of this background the researcher interest to do a research.

Objective: to analyze the effectiveness of using audio visual methods to increase adolescent knowledge about premarital sex in SMAN 1 Sungai Kakap in 2018.

Research Method: one group of pre-posttest design was conducted in this study. The population of this study is all students of $X$ and IX grade in SMAN 1 Sungai Kakap. 56 students who ready to be a responden with fill the informed consent before and adolescent were $15^{\text {th }}-19^{\text {th }}$ years old. were recruited as samples. Wilcoxon Test was used to analyzed data.

Remaja usia 15-19 tahun

Results: The average knowledge was raised as much 31,58\% (from 59.8 to 87.4 ). Wilcoxon Test results obtained $p$ value $=0,000(p<0.05)$, from the results showed that there was a difference between the knowledge of respondents before and after given a health education about the dangers of premarital sex meant significant.

Conclusion: Audio visual method could be an effective method in providing health education to increase adolescent knowledge about premarital sex in adolescents.

Suggestion Audio Visual Method can be used as an alternative in increasing adolescent knowledge about premarital sex
\end{abstract}

Keywords: Audio Visual, Premarital Sex

\section{ABSTRAK}

Latar belakang: Survei menemukan alasan hubungan seksual pranikah adalah; rasa ingin tahu $(57,5 \%$ dilaporkan oleh laki-laki), tidak sengaja terjadi dan dipaksa oleh pasangan dilaporkan oleh wanita ( $38 \%$ dan $12,6 \%$ ). Hasil dari wawancara dengan 10 siswa menemukan 9 siswa telah berpacaran dan kebanyakan dari mereka tidak tahu tentang seks pranikah. Pendidikan kesehatan adalah salah satu upaya yang dapat dilakukan untuk memberikan informasi yang tepat dan akurat terkait bahaya seks pranikah pada remaja. Metode yang dapat dilakukan untuk mendukung pelaksanaan pendidikan kesehatan adalah ceramah, pamflet, selebaran dan audio visual. Audio visual dapat membuat seseorang lebih berkonsentrasi dan perhatian dan dapat mendorong aktivitas diri (Musfiqon, 2012). Berdasarkan latar belakang ini maka peneliti tertarik untuk melakukan penelitian.

Tujuan: untuk menganalisis efektivitas penggunaan metode audio visual untuk meningkatkan pengetahuan remaja tentang seks pranikah di SMAN 1 Sungai Kakap pada tahun 2018.

Metode Penelitian: satu kelompok desain pre-posttest dilakukan dalam penelitian ini. Populasi penelitian ini adalah semua siswa kelas $X$ dan IX di SMAN 1 Sungai Kakap. 56 siswa yang siap menjadi responden dengan mengisi informed consent sebelum dan remaja berusia 15-19 tahun. direkrut sebagai sampel. Uji Wilcoxon digunakan untuk menganalisis data. 
Remaja usia 15-19 tahun

Hasil: Pengetahuan rata-rata dinaikkan sebanyak 31,58\% (dari 59,8 menjadi 87,4). Hasil Uji Wilcoxon diperoleh nilai $p=0,000(p<0,05)$, dari hasil penelitian menunjukkan bahwa ada perbedaan antara pengetahuan responden sebelum dan sesudah diberikan pendidikan kesehatan tentang bahaya seks pranikah berarti signifikan.

Kesimpulan: Metode audio visual bisa menjadi metode yang efektif dalam memberikan pendidikan kesehatan untuk meningkatkan pengetahuan remaja tentang seks pranikah pada remaja.

Saran: Metode Audio Visual dapat digunakan sebagai alternatif dalam meningkatkan pengetahuan remaja tentang seks pranikah

Kata kunci: Audio Visual, Seks Pranikah

\section{PENDAHULUAN}

Masa remaja merupakan salah satu periode perkembangan manusia. Masa ini merupakan masa transisi dari kanak-kanak menuju dewasa meliputi perubahan biologi, psikologi dan sosial. Menurut World Health Organization (WHO) remaja adalah mereka yang berada pada usia 12-24 tahun. Mereka cenderung lebih mudah melakukan penyesuaian dengan arus globalisasi dan arus informasi yang bebas yang dapat menyebabkan terjadinya perubahan perilaku menyimpang. Salah satu perilaku menyimpang yaitu seks pra nikah. Seks pra nikah adalah segala tingkah laku yang didorong oleh hasrat seksual dengan lawan jenis sebelum menikah. Dari survey didapatkan alasan hubungan seksual pranikah tersebut sebagian besar karena penasaran/ingin tahu $(57,5 \%)$, terjadi begitu saja (38\%) dan dipaksa oleh pasangan (12,6\%).

Menurut United Nation Development Economic And Social Affairs (UNDESA, 2010 ), Indonesia termasuk Negara ke-37 dengan presentase pernikahan usia muda yang tinggi dan merupakan tertinggi kedua di ASEAN setalah Kamboja. Pendidikan Kesehatan merupakan salah satu upaya yang dapat dilakukan untuk memberikan informasi yang tepat dan akurat berkaitan bahaya seks pra nikah pada remaja. Metode yang dapat dilakukan untuk mendukung terlaksananya pendidikan kesehatan yaitu ceramah, pamphlet, leaflet dan audio visual. Kebanyakan pendidikan kesehatan menggunakan metode ceramah, karena lebih murah, tetapi metode audio visual dapat meningkatkan perhatian seseorang dengan menampilkan tampilan yang menarik, metode audio visual (video) dapat membuat seseorang takut akan tertinggal jalannya video tersebut sehingga ia akan lebih konsentrasi dan perhatian. Media Audio Visual menampilkan hal-hal yang tampak nyata sehingga mendorong adanya aktivitas diri (Musfiqon, 2012).

Angka pernikahan dini usia 10-19 tahun di Kalimantan Barat mencapai 47,8\% sedangkan nasional adalah 46,7\% (RIKESDA 2010). Survei
Demografi dan Kesehatan Indonesia (SDKI) Tahun 2012 menunjukkan Angka Kelahiran Menurut Kelompok (Age Specifik Fertility Ratel ASFR) 15-19 di Provinsi Kalimantan Barat mencapai 104. Artinya dari 1000 kelahiran, 104 diantaranya adalah dilahirkan oleh ibu berumur 15-19 tahun. Sementara pada tahun yang sama ASFR rata-rata nasional hanya mencapai 48. Angka 104 ini sekaligus menempatkan provinsi Kalimantan Barat tertinggi secara nasional. Menurut hasil survey di BKKBN Kalimantan Barat tahun 2014, terhadap 88 calon pengantin di wilayah kerja Puskesmas Sungai Kakap mencapai $63,6 \%$ persen positif hamil. SMA Negeri 1 Sungai Kakap memiliki 23 kelas dengan jumlah siswa sebanyak 794 siswa. Jumlah siswa di kelas $X$ dan Kelas XI sebanyak 556 siswa. Berdasarkan hasil wawancara kepada 10 orang siswa didapatakan 9 orang pernah berpacaran dan sebagian besar dari mereka belum pernah mendapatkan penyuluhan tentang seks pranikah.

Berdasarkan latar belakang di atas maka dapat dirumuskan masalah dalam penelitian ini yaitu "Apakah terdapat perbedaan peningkatan pengetahuan remaja sebelum dan sesudah diberikan penyuluhan tentang bahaya seks pranikah dengan metode audio visual di SMAN 1 Sungai Kakap Tahun 2018"

\section{METODE \\ Populasi dan Sampel}

Populasi dalam penelitian ini adalah seluruh siswa kelas $X$ dan kelas IX di SMAN 1 Sungai Kakap yang berjumlah 556 siswa. Sampel penelitian adalah objek yang diteliti dan dianggap mewakili seluruh populasi (Notoatmodjo, 2012). Untuk mendapatkan data sesuai dengan focus penelitian ini, maka peneliti menentukan sampel dengan kriteria sebagai berikut:

a) Bersedia menjadi responden dengan mengisi persetujuan sebagai responden.

b) Remaja usia 15-19 tahun. 
Menurut Arikunto (2010), jika jumlah populasi besar maka dapat diambil antara $10-15 \%$ atau $20-25 \%$ atau lebih. Dalam penelitian ini, peneliti mengambil $10 \%$ dari jumlah populasi yaitu kelas $X$ dan IX yang memenuhi kriteria. Besarnya sampel dalam penelitian yaitu 56 orang responden. Pengambilan sampel dalam penelitian ini menggunakan teknik simple random sampling.

\section{Rancangan Penelitian}

Merupakan penelitian kuantitatif dengan desain penelitian one group pretest-posttest tanpa kelompok pembanding (kontrol). Populasi dalam penelitian ini adalah seluruh siswa kelas $X$ dan IX di SMAN 1 Sungai Kakap berjumlah 556 siswa. Jumlah sampel diambil 10\% (Arikunto,2010) yang berjumlah 56 siswa (masuk dalam kriteria inklusi) dengan teknik simple random sampling. Uji normalitas yang digunakan adalah Kolmogorov-Smirnov Test dan analisis data menggunakan Uji Wilcoxon.

\section{Instrumen Penelitian}

Instrumen yang digunakan dalam penelitian ini adalah kuesioner atau angket. Jawaban yang benar diberikan skor 1 dan jawaban yang salah diberikan skor 0 . Kemudian dihitung total skor akhir. Kuesioner untuk menilai pengetahuan remaja tentang seks pranikah meliputi pengertian, bentukbentuk seks pra nikah, faktor-faktor terjadinya seks pra nikah, dampak seks pra nikah dan cara pencegahan seks pra nikah terdiri dari 12 item,

\section{Rancangan Analisis}

Data dilakukan terlebih dahulu uji normalitas untuk mengetahui apakah data berdistribusi normal atau tidak. Analisis univariat untuk melihat distribusi frekuensi. Analisis bivariat, uji Wilcoxon (data tidak berdistribusi normal) dilakukan untuk menganalisis perbedaan nilai pre test dan post test.

\section{Tempat dan Waktu Penelitian}

Penelitian ini dilakukan di SMAN 1 Sungai Kakap wilayah kerja Puskesmas Sungai Kakap Kabupaten Kubu Raya dan dilaksanakan mulai bulan JuliAgustus 2018.

\section{Etik Penelitian}

Penilitian ini telah mendapatkan Rekomendasi Persetujuan Etik Oleh Komisi Etik Penelitian Kesehatan Politeknik Kesehatan Pontianak dengan No.028/KEPK-PK.PKP/VII/2018.

\section{HASIL PENELITIAN}

Hasil penelitian ini meliputi analisis deskriptif (univariat) yang menggambarkan data karakteristik responden. Karakteristik umur dan jenis kelamin siswa -siswi kelas X dan XI di SMA N 1 Sungai Kakap Pontianak dapat dilihat pada tabel di bawah ini.

Tabel 1 Distribusi Frekuensi Responden Berdasarkan Kategori Umur dan Jenis Kelamin di SMA N 1 Sungai Kakap Tahun 2018

\begin{tabular}{|c|c|c|c|}
\hline No. & Karakteristik & $\mathrm{N}$ & $\%$ \\
\hline \multirow[t]{6}{*}{1} & Usia & & \\
\hline & - 15 Tahun & 5 & 8.9 \\
\hline & - 16 Tahun & 24 & 42.9 \\
\hline & - 17 Tahun & 24 & 42.9 \\
\hline & - 18 Tahun & 3 & 5.4 \\
\hline & Total & 56 & 100.0 \\
\hline \multirow[t]{4}{*}{2} & Jenis Kelamin & & \\
\hline & - Perempuan & 26 & 46.4 \\
\hline & - Laki-laki & 30 & 53.6 \\
\hline & Total & 56 & 100.0 \\
\hline
\end{tabular}

Berdasarkan tabel diatas, usia responden yang dominan adalah 16 dan 17 tahun dengan hasil persentase sama yaitu masing-masing $42,9 \%$. Jenis kelamin responden sebagian besar yaitu laki-laki dengan persentase $53,6 \%$.

Analisis perbedaan pre tes dan pos tes bertujuan untuk melihat perbedaan dan peningkatan antara nilai pre tes dan pos tes yang disebabkan oleh Penyuluhan Kesehatan tentang bahaya seks pra nikah. Aspek yang dinilai dalam penelitian ini yaitu perbedaan dan peningkatan pengetahuan. Peningkatan nilai pengetahuan dapat dilihat pada tabel 1.2 berikut :

Tabel 2 Analisis Statistik Perbedaan Pengetahuan Sebelum dan Sesudah Intervensi Penyuluhan Kesehatan Dengan Metode Audio Visual

\begin{tabular}{lcccc}
\hline \multicolumn{1}{c}{ Variabel } & Pre test & Post test & Sig & \% peningkatan \\
\hline Pengetahuan & & & & \\
Median & 58,3 & 91,7 & \multirow{2}{*}{0,000} & 31,58 \\
Min - Maks & $50-88,3$ & $66,7-100$ & & \\
\hline
\end{tabular}


Berdasarkan hasil analisis data ressponden didapatkan pengetahuan sebelum diberikan penyuluhan yaitu nilai median yaitu 58,3 , serta nilai minimum 50 dan maksimum 83,3. Pengetahuan sesudah diberikan penyuluhan yaitu nilai median yaitu 91,7 , serta nilai minimum 66,7 dan maksimum 100. Hasil uji normalitas data menggunakan uji Kolmogorov-Smirnov Test didapatkan nilai $p=0,000$ sebelum diberikan penyuluhan dan $p=0,013$ sesudah diberikan penyuluhan, data tersebut dinyatakan berdistribusi tidak normal dikarenakan $p<0,05$. Setelah dilakukan analisis menggunakan uji Wilcoxon diperoleh nilai $p=0,000(p<0,05)$ sehingga Ha diterima, yaitu terdapat perbedaan pengetahuan remaja putri sebelum dan sesudah diberikan penyuluhan dengan power point tentang bahaya seks pra nikah dengan hasil peningkatan sebelum dan sesudah penyuluhan $31,58 \%$.

\section{PEMBAHASAN}

Distribusi frekuensi pengetahuan remaja tentang bahaya seks pra nikah sebelum dilakukan penyuluhan kesehatan didapat nilai minimum 50 , nilai maximum yaitu sebesar 83 dan setelah penyuluhan nilai minimum 66,7 , nilai maximum yaitu sebesar 100 hal ini menunjukan bahwa setelah diberikan penyuluhan pengetahuan meningkat. Dari hasil penelitian terhadap 56 responden menunjukan terdapat perbedaan antara pengetahuan responden sebelum dan sesudah diberikan penyluhan tentang bahaya seks pra nikah terhadap remaja dimana didapatkan bahwa $p=0.000$ lebih kecil dari 0.005 berarti perbedaan pengetahuan yang signifikan sebelum dan sesudah diberikan penyuluhan kesehatan tentang bahaya seks pra nikah.

Menurut Notoatmodjo (2007) salah satu faktor yang mempengarui tingkat pengetahuan adalah pendidikan, pendidikan adalah usaha untuk mengembangkan kepribadian dan kemapuan didalam dan diluar sekolah (baik formal maupun nonformal). Contoh pendidikan nonformal yaitu penyuluhan kesehatan. Penyuluhan kesehatan ialah suatu kegiatan atau usaha menyampaikan pesan kesehatan kepada masyarakat, kelompok, individu. Dengan adanya pesan tersebut diharapakan masyarakat, kelompok, atau individu dapat memperoleh pengetahuan tentang kesehatan yang lebih baik (Notoatmodjo, 2007). Semangkin banyak informasi yang masuk semankin banyak pula pengetahuan yang didapat tentang kesehatan.

Menurut Machfoedz (2009) Metode audio visual merupakan metode yang menarik, sederhana dan mudah dimengerti, sehingga mampu menggambarkan apa yang menjadi maksud dalam materi atau penyuluhan yang akan diberikan. Metode audio visual dapat menimbulkan beberapa perubahan, misalnya perubakan prilaku, meningkatnya pengetahuan,, mempengaruhi tahap bertahan, menguatkan nilai, menengahi faktor dan mempengaruhi psikologis. Metode audio visual dapat lebih mempermudah penyampaian dan penerimaan informasi atau bahan pendidikan. Hal ini juga didukung oleh penelitian Rizka (2010) bahwa keberhasilan belajar siswa dipengaruhi oleh berbagai faktor,salah satu faktor yang penting adalah penggunaan metode pada proses pembelajaran.

Penelitian ini sejalan dengan penelitian yang dilakukan oleh Nuzulia Rahayu (2013) yaitu pengaruh kegiatan penyuluhan tentang bahaya seks pra nikah terhadap pengetahuan dan sikap siswa di SMA Negeri 1 Lubuk Dalam Kab. Siak Sri Indrapura yang menunjukkan responden berpengetahuan baik $39 \%$ sebelum dan $80,4 \%$ setelah dilakukan penyuluhan dengan hasil $\mathrm{P}=0.000$ yang berarti penyuluhan mempengaruhi pengetahuan dan sikap siswa tentang bahaya seks pra nikah.

Pendidikan kesehatan reproduksi yang efektif menjadi tanggung jawab individu. Program pendidikan yang diperlukan individu dapat memberikan informasi yang diperlukan dalam mengambil keputusan seksual yang etis. Pendidikan akan mencapai tujuan lebih baik bila didukung atau menggunakan media pembelajaran. Pentingnya media massa dalam penyuluhan kesehatan dalam pencegahan penyakit, penggunaan media sangat berpengaruh terhadap peningkatan pengetahuan dan perubahan perilaku kesehatan. Selain itu penggunaan metode dalam penyuluhan kesehatan juga sangat berpengaruh salah satunya penggunaan metode audio visual dalam penyampaian penyuluhan kesehatan tentang bahaya seks pra nikah selain penggunaan yang sangat ekonomis juga dapat diterima disetiap kalangan usia.

\section{KESIMPULAN}

Metode audio visual merupakan metode yang efektif dalam pemberian pendidikan kesehatan untuk meningkatkan pengetahuan remaja tentang seks pranikah pada remaja. Metode audio visual dapat menarik perhatian remaja dengan menampilkan tampilan yang menarik, metode audio visual (video) dapat membuat seseorang takut akan tertinggal jalannya video tersebut sehingga ia akan lebih konsentrasi dan perhatian.

\section{SARAN}

Metode Audio Visual dapat dijadikan salah satu alternative dalam menambah Pengetahuan Remaja Tentang Seks Sebelum Menikah 


\section{DAFTAR PUSTAKA}

Arikunto, Suharsimi. 2006. Prosedur Penelitian Suatu Pendekatan Praktik. Jakata : Rineka Cipta.

Badan Pusat Statistik, Badan Kependudukan dan Keluarga Berencana, \& Kementerian Kesehatan RI. 2012. Survei Demografi dan Kesehatan Indonesia 2012. Diakses melalui http://chnrl.org/pelatihan-demografi/SDKI2012.pdf tanggal 28 Februari 20168.

Cahyo, A. N (2011). Berbagai Cara Latihan Otak dan Daya Ingat dengan Menggunakan Ragam Media Audio Visual. Jogjakarta : Diva Press

Dinkes Kalimantan Barat. 2014. Profil Kesehatan Kalimantan Barat Tahun 2014.

Handoyo. 2010. Remaja dan Kesehatan. Jakarta : Perca

Machfoeds. 2013. Metode Penelitian. Yogyakarta : Fitramaya

Musfiqon. 2012. Pengembangan Media dan Sumber Pembelajaran. Jakarta : Prestasi Pustaka Raya

Notoatmodjo. 2007. Promosi Kesehatan \& IImu Perilaku. Jakarta : Rineka Cipta 2010.Metode Penelitian. Jakarta : Rineka Cipta
2012. Promosi kesehatan dan perilaku kesehatan. Jakarta : Rineka Cipta

Purnamawati, Desi. 2013. Perbedaan pengaruh pendidikan kesehatan menggunakan leafleat dengan audiovisual terhadap tingkat pengetahuan remaja tentang bahaya minuman keras di desa wates simo boyolali. Diakses melalui http://eprints.ums.ac.id/26014/15/NASKAH PUBLIKASI.pdf, tanggal 10 Maret 20

Sadiman (2002). Pendekatan Pembelajaran Contextual Teaching Learning (CTL).Jakarta : Rajawali Press

Sanjaya W. 2010. Strategi Pembelajaran: Berorentasi Standar Proses Pendidikan.Jakarta: Kencana.

Sarwono J. 2006. Metodologi Penelitian. Yogyakarta : Graha IImu

Sugiyono. 2012. Statistika Untuk Penelitian. Bandung : Alfabeta.

Syafrudin \& Fratidhina, Y. 2009. Promosi Kesehatan Untuk Mahasiswa Kebidanan. Jakarta : Trans Info Medika

Swarjana. 2016. Statistik Kesehatan. Yogyakarta: CV. Andi 